\title{
ATIVIDADES DE CRIAÇÃO NOS NOVOS MODOS DE PRODUÇÃO E DE RELAÇÕES DE EMPREGO
}

\author{
por Tânia Cristina Alves de Siqueira*
}

MENGER, Pierre-Michel. O retrato do artista enquanto trabalhador: metamorfoses do capitalismo. Lisboa: Roma Editora, 2005.

Pierre-Michel Menger é sociólogo, pesquisador do Centre National de la Recherche Scientifique (CNRS), diretor de pesquisa na École des Hautes Études en Siences Sociales (EHSS). Os seus principais eixos de estudos são: as artes, os seus mercados e os seus sistemas de avaliação; o trabalho e o emprego nas artes e a cultura, eos tempos de lazer e de trabalho no emprego dos franceses. Publicou Le paradoxe du musicien (Paris: Flammarion, 1983) e La profession de comédien (Paris: La Documentation Française, 1998).

Em seu estudo, objeto desta resenha, a proposta do autor é compreender o artista e o processo de criação a partir da categoria trabalho. Para o autor as atividades de criação não são ou deixaram de ser a face oposta do trabalho e são cada vez mais assumidas como a expressão mais avançada dos novos modelos de produção e das novas referências de emprego engendradas pelas mutações do capitalismo.

Como assinala o autor:

o nosso tempo não é mais o das representações herdadas século XIX, que opunham o idealismo sacrificial do artista e o materialismo do trabalho calculado, ou a figura do criador, original, provocador e

* Tânia Cristina Alves de Siqueira é doutoranda do Programa de Pós-Graduação em Sociologia da Universidade de Brasília. 
insubmisso. Nas representações atuais, o artista é quase uma encarnação possível do trabalhador do futuro, com a figura do profissional inventivo, móvel, indócil às hierarquias, intrinsecamente fundamentado, tomados numa economia do incerto e mais expostos aos riscos de concorrência interindividual e às novas inseguranças das trajetórias profissionais (p. 45).

Distante das representações românticas, contestatórias ou subversivas do artista seria necessário doravante olhá-lo como uma figura exemplar do novo trabalhador. Neste sentido, Menger faz a pergunta: o artista seria a última "metamorfose" do capitalismo e a arte, por sua vez, uma espécie de "princípio de fermentação do capitalismo" onde o artista encarnaria o trabalhador do futuro, uma espécie de ideal possível do trabalho qualificado de alto valor? O que o trabalho artístico oculta que possa ser ensinado outros aos modos de produção?

Segundo Menger, há várias coisas a serem ensinadas tais como: uma hiperflexibilidade da mão-de-obra, o fim de certas formas de controle e de hierarquização em proveito da valorização e desenvolvimento do indivíduo, a descoberta do talento como fator complementar de produção, e, por último, o fim de um sentimento de alienação dado que cessa a concorrência entre a vida e o trabalho. Segundo o autor, o artista e o trabalhador dos tempos pós-industriais fundiriam, em uma e mesma figura, o "criativo".

A arte não é mais somente o oposto do trabalho, mas ficaria como o duplo que não foi confessado, o seu protótipo futurista. Para tanto é necessário demonstrar que o capitalismo soube integrar alguns dos valores que lhe eram a priori mas alheios e, não somente na sua literatura mas na sua prática.

A reflexão sobre as atividades de criação remete-nos a questões que se relacionam às relações entre as artes e a economia de mercado capitalista. Na primeira parte do livro, o autor reavalia diferentes posições teóricas para construir o retrato do artista como trabalhador. Identifica vários discursos sobre a questão do trabalho de criação. Por um lado, a arte está essencialmente fora das outras esferas de 
produção; por outro, a arte pode estar sujeita à força do mercado e por isso o melhor é opor uma resistência interna. Nos discursos analisados pelo autor, as artes não seriam da competência do trabalho comum, nem ocultariam nenhuma forma de exemplaridade, e, além disso, não teriam nada a ensinar aos outros mundos de produção. Para Menger, esses discursos não são eficazes para se compreender a produção artística hoje.

Segundo o autor, há uma "evolução homóloga das diferentes esferas de produção, incluindo aqui as artes, que tira partido e se utiliza de certas características fundamentais do mundo da invenção artística para calibrar as boas práticas do trabalho e da sua organização perante os desafios contemporâneos". Podese, então, pensar os ensinos eventuais da arte para os outros mundos de produção, a começar pela divisão de trabalho que a "segmentação cada vez mais fina das especialidades” organiza uma divisão funcional de trabalho que confirma "relações de interdependência, indo da cooperação à concorrência e ao conflito, mas não o situa numa hierarquia direta e organizada”. Menger destaca que, hoje, essencialmente, as atividades criativas são feitas em organizações por projeto ou modelos mistos, e que as formas "duradouras e disciplinantes" de supervisão sofrem a mesma erosão e a mesma fragmentação salarial às quais eram associadas e que, na divisão do trabalho artístico, há a coexistência de dois princípios: o individualismo e o risco.

A individualização das relações permite mais autonomia e responsabilidade, mas esta valorização das atividades artísticas “impõe também aos profissionais benefícios e penalidades diretamente expressos em possibilidades de emprego, de mobilidade ascendente nas redes cooptação".

Um outro problema colocado pelas atividades artísticas referese aos critérios que determinam ou determinarão o valor do trabalho quando o que está em questão é a noção de talento. 
No mundo das artes, como no dos esportes, as desigualdades de remuneração não são somente toleradas, mas afirmadas ou mesmo celebradas: "O instrumento de medida dos talentos e de sua tarifação fornece, sob a aparência indolor e excitante de um pátio da fama, a apologia mais surpreendente da concorrência interindividual” (p. 73). Nesse contexto quais podem ser as "desigualdades legitimáveis"?

Um dos critérios reside no fato de que o desempenho do profissional tanto possa ser julgado "por comparação e aposta em concorrência direta com outros trabalhadores e profissionais", assim como o seu trabalho possa ser identificado separadamente e não confundido no desempenho global de uma equipe, o que supõe "uma figura econômica e jurídica do desempenho individual".

Se a arte aparece como o terreno de experimentações singulares e inovadoras através do qual se constrói um novo mundo do trabalho, convém notar a preocupação constante dos criadores de socializar a noção de risco para diversos mecanismos, dentre os quais o mais notável é, efetivamente, o regime de indenização do desemprego dos intermitentes do espetáculo, tão específico porque único no seu tipo.

O mundo da criação longe de ser homogêneo é minado estruturalmente pelas desigualdades: fato que se reflete na equação inversamente proporcional entre "o número de indivíduos que se auto-identificam como artistas de profissão e o volume de trabalho disponivel”.

As formas dominantes da organização do trabalho nas artes atividade não assalariada, o auto-emprego, o free-lancing e as diversas formas atípicas do trabalho (intermitência, tempo parcial, etc.) - parecem não mais estar em condições de se oporem ferozmente ao mercado, uma vez que são atividades já integradas numa lógica da qual participam voluntariamente ou não.

Por fim gostaria de ressaltar que esse estudo é um instrumento extremamente útil para a compreensão dos fenômenos muito contemporâneos ligados à flexibilidade do trabalho aplicado à atividade 
artística e ao processo de criação no qual ainda residem representações impróprias. Para o autor, futuramente seremos todos artistas, isto é, artistas no que diz respeito aos trabalhadores qualificados, cujas formas de emprego - não necessariamente o conteúdo do trabalho, naturalmente - irão se aproximar daquelas condições que são bem conhecidas pelos intermitentes do espetáculo.

\section{Referências bibliográficas}

FLEURY, Cynthia. Le travailleur et l'artiste. 2004. Disponível em: Les Croniques de l'Humanité: 〈http://www.humanite.presse.fr/journal〉.

PECH, Thierry. Pierre Michel Menger et l'économie de la production artistique. 2002. Disponível em: La Republique des Idées <http:// www.repid.com.>. 